\title{
ETNOGRAFANDO NARRATIVAS ÉTNICAS NO ESPAÇO DA CIDADE: OS NEGROS E AS AÇÕES AFIRMATIVAS NA SOCIEDADE BRASILEIRA CONTEMPORÂNEA ${ }^{1}$
}

\author{
Margarete Fagundes Nunes ${ }^{2}$ \\ Ana Luiza Carvalho da Rocha ${ }^{3}$
}

\section{Introdução}

A sociedade brasileira vem apresentando algumas mudanças no trato com a diversidade étnico-racial, especialmente no que tange ao posicionamento do Estado nacional em relação à aplicação das políticas de ações afirmativas para as populações negras e indígenas. ${ }^{4}$ Tem-se, mais especificamente neste primeiro decênio dos anos 2000, um conjunto de medidas acionadas pelo Estado a partir da interlocução com os movimentos sociais, visando consolidar políticas públicas de caráter particularizante que atendam algumas demandas históricas desses grupos. Não obstante essas iniciativas, as tais mudanças são lentas, graduais e provocam inúmeras indagações. No que diz respeito à antropologia, e as ciências sociais como um todo, não faltaram momentos e espaços para o aprofundamento do debate acerca das implicações dessas políticas para a sociedade brasileira. Não é nosso interesse, aqui, retomar todo esse debate, muito menos acirrar a polarização entre os pró-ações afirmativas x os contras, tendo em vista que se os impasses teóricos ainda não estão resolvidos, já se constata certo abrandamento dessa discussão.

Nossa intenção, com este artigo, é socializar algumas indagações e reflexões que foram tomando corpo ao longo desse tempo, às quais estão diretamente ligadas às nossas práticas de pesquisa. Por um lado, buscamos compreender a linguagem da etnicidade ${ }^{5}$ nas cidades brasileiras contemporâneas, via ações afirmativas (Nunes, 2009); por outro, buscamos relacionar esse movimento com os estudos da memória individual e coletiva, lançando mão da "etnografia da duração” como um caminho através do qual o antropólogo pode chegar ao conteúdo simbólico da cidade (Eckert e Rocha, 2005).

\footnotetext{
${ }^{1}$ Esse artigo resulta do material de pesquisa da tese de doutorado defendida na UFSC sob a orientação da Profa. Carmen Silvia Rial e co-orientação da Profa. Ana Luiza Carvalho da Rocha.

${ }^{2}$ Centro Universitário Feevale, Brasil.

${ }^{3}$ Universidade Federal do Rio Grande do Sul e Universidade Federal de Santa Catarina, Brasil.

${ }^{4}$ Roger Raupp Rios (2006), quando define ações afirmativas, lembra que o conceito nasceu vinculado à luta pela superação do racismo na sociedade norte-americana, sendo mais tarde incorporado na pauta de reivindicações de outros grupos étnicos e também para combater as discriminações de gênero. Independente da extensão do conceito, o autor demonstra que o seu desenvolvimento ligou-se à formulação de respostas jurídicas às modalidades de discriminação experimentadas por determinados grupos em virtude do racismo e outras formas de preconceito.

${ }^{5}$ Sobre a expansão do uso do conceito de etnicidade no pensamento social contemporâneo, ver Poutignat e StreiffFenart (1998).
} 
Partimos do entendimento de que a aplicação de algumas políticas de ações afirmativas introduz modificações no cenário urbano, na ocupação do espaço e nos intrincados jogos e disputas pelo poder econômico e político. Por exemplo, a patrimonialização de áreas de remanescentes de quilombos, bem como daquelas destinadas às populações indígenas, tem conduzido diversos grupos urbanos a uma mobilização crescente pelo reconhecimento de territórios marcados por seus traços étnicos, isto é, nas formas com que as paisagens das cidades revelam a persistência de tais traços, tangíveis ou intangíveis. Corroboramos a ideia de que a partir do final do século XX, acentuando-se nos anos 2000, assiste-se a um processo de etnicização da vida urbana no Brasil - em alguns casos quiçá de “racialização” - no qual se verifica que os conceitos e categorias de interpretação do antropólogo muitas vezes se mesclam às lutas pelo direito das minorias.

Portanto, a linguagem da etnicidade é o eixo a partir do qual realizamos o movimento de pensar a cidade enquanto espaço social para os jogos da memória e da produção da diferença (Eckert e Rocha, 2005), dos sujeitos e dos grupos que nela habitam, e que fazem dela um “espaço” polissêmico, onde a produção de sentido não se esgota na totalidade territorial que ela engloba, mas se espraia pela relação construída com outros “lugares”, pelas comunicações “transculturais”6 características da vida urbana contemporânea.

Ao falarmos de produção de sentido chamamos a atenção para os aspectos simbólicos dos quais se revestem o tempo e o espaço por ocasião da fabricação das narrativas sobre a cidade. Remetemo-nos à discussão de Maffesoli (1995;1999) para destacar aqueles elementos que animam o cotidiano: as imagens partilhadas, a comunidade de sentimento, a pulsão estética do sensível.

Não obstante, para efeito de uma análise interpretativa, consideramos as articulações entre o local e o global nas atuais políticas identitárias, chamando a atenção para os ecos das discursividades étnicas no Brasil contemporâneo e os questionamentos, daí decorrentes, acerca das fronteiras simbólicas da identidade nacional (Nunes, 2009). Questionamentos esses que alcançam também as fronteiras das identidades regionais e locais, pois se as ações afirmativas

\footnotetext{
6 A noção de sociedade transcultural ou translocal é recorrente em Sahlins (1997), que chama a atenção para aquelas formações culturais que atravessam fronteiras e desafiam a imaginação antropológica. Quando a utilizamos aqui queremos enfatizar as possibilidade de comunicação entre os lugares, sem, no entanto, desconsiderar as relações assimétricas que resultam desses contatos.
} 
clamam por alguma resposta à indagação “Que país é este?”, clamam do mesmo modo em relação à região e à cidade.

Acreditamos, portanto, que as ações afirmativas nos desafiam a problematizar a desigualdade racial/étnica da vida urbana no Brasil não apenas do ponto de vista social e material, mas, sobretudo, em relação às imagens e representações acerca desses cenários. Ao se inserirem no jogo da etnicização das paisagens urbanas, os negros estabelecem novos parâmetros para a discussão da democratização dos espaços da cidade e da equidade na formulação e implementação das políticas urbanas, sociais e culturais. ${ }^{7}$ Observamos que a memória emerge como um recurso político para os movimentos de afirmação identitária; é acionada pelos sujeitos e os grupos como uma “comprovação” do seu lugar na cidade e no desenrolar do tempo; configura-se como um modo de agenciar o acesso aos bens materiais, culturais e simbólicos da cidade.

\section{A Cidade e a pluralidade de memórias}

A cidade, que em estudos clássicos já foi apontada como sendo desagregadora das relações sociais, o lugar da brevidade e da escassez dos contatos inter-humanos, onde prepondera o espírito objetivo e marginaliza-se o emocional (Simmel, 1967); marcada pelas relações fortuitas e destituída da solidariedade folk (Park, 1967); lugar da desestruturação dos laços da família, do parentesco e da solidaridade social (Wirth, 1967); hoje, desponta na teoria social como o espaço de formação das “comunidades emocionais” e do “tribalismo” (Maffesoli, 1987); lugar das múltiplas vozes (Canevacci, 1997); da diversidade de estilos de vida e estratificações sociais (Velho, 1989); dos arranjos, redes, trocas e encontros nos pedaços, manchas e trajetos do espaço (Magnani, 1996, 2003); lugar da pluralidade de memórias e da sobreposição de tempos (Eckert \& Rocha, 2005).

O discurso da localidade plural repercute nos estudos urbanos contemporâneos. A ênfase no "local”, animada pela globalização cultural, inspira a formulação de novas competências para as esferas regionais e municipais. A cidade emerge como o lugar por excelência da produção e da manifestação das identidades, como também do ocultamento e do silêncio dos "subalternos”, fiéis

\footnotetext{
${ }^{7}$ Estamos considerando aqui as diferentes políticas públicas, desde as ligadas ao saneamento urbano, como aquelas ligadas aos serviços de saúde, educação, moradia, assistência social, até as políticas que envolvem a valorização do patrimônio material e imaterial dos grupos, como os saberes, as expressões artísticas, as crenças e festas populares etc.
} 
representantes das “não-identidades.”8 Na cidade é que o "plural” alcança a sua plenitude. Ela encerra de forma mais categórica os diferentes jogos de associações ou conflitos. O étnico e o “tradicional” deslocam-se, passam a ocupar o mosaico das cidades, mesclam-se ao "moderno" e ajudam a encenar o “diverso" e o "plural”.

Vivenciamos na contemporaneidade o alastramento das ideias em torno de identidade, diferença, pluralidade e diversidade. Hoje, os Estados nacionais são intimados a rever suas ações a fim de atender o “diverso”, por vezes, traduzindo esse movimento por meio de políticas públicas. As cidades tornam-se um palco privilegiado para a tradução e concretização da relação local/global. Mais do que (re) inventar o local as cidades passam a se organizar para a diversidade.

Nesta direção, ganham novo impulso os estudos sobre identidade, imigração e etnicidades, mergulhados num movimento em que indivíduos, grupos e comunidades buscam reconstituir itinerários e resguardar valores e fragmentos de um “passado” e de uma "tradição" idílicos, frente a um mundo em que as palavras-chave são velocidade, efemeridade e instantaneidade. $^{9}$

As distintas formas de constituição dos Estados nacionais, bem como as atuais singularidades políticas de convivência com o “diverso”, não raras vezes conflituosas - por exemplo, a Espanha, com os bascos e catalões; a cidade de Paris/França, com os argelinos, marroquinos etc; Londres/Inglaterra, com indianos, paquistaneses etc; Berlim/Alemanha, com os turcos e africanos, etc - têm conduzido a uma reflexão sobre o reconhecimento da diferença e os processos de etnicização da vida social. O Brasil dá sinais de migração para este processo peculiar que preside as regras de ocupação e apropriação das cidades típicas do mundo urbano contemporâneo.

As cidades do novo milênio aparecem inseridas num continuum de fabricação do “diverso” e do “plural”. A tendência à “exclusão e à fragmentação” é algo que “percorre o nosso tempo, criando diferenças de sexos, diferenças étnicas, diferenças culturais, diferenças regionais,

${ }^{8}$ Fazemos referência ao trabalho de Mary Garcia Castro, que nos alerta para os silêncios que fluem na globalização da cultura. Num momento em que todas as atenções voltam-se para as identidades, a autora desperta para os processos que asseguram a existência das “não-identidades”. Ver Castro, in: Feldman-Bianco; Capinha (2000: 149-175).

${ }^{9}$ O antropológo Marc Augé (1997) salienta a importância que adquire o indivíduo nos estudos antropológicos contemporâneos. A história oral é uma fonte privilegiada para a reconstituição dos itinerários e a compreensão dos diversos "mundos” que constituem as cidades. 
diferenças nacionais”. (Rocha, 2001:3) Isto traz para o centro do debate antropológico o questionamento do conceito de identidade, a partir do qual tanto se pode abordar o localismo da diferença quanto a unidade globalizante.

Compartilhamos o entendimento de que se faz urgente e necessária uma interpretação da cidade, e da democratização dos seus espaços, que leve em conta as discursividades étnicas presentes no mundo urbano contemporâneo. Todavia, lembramos dos desdobramentos teóricometodológicos que envolvem essa perspectiva de análise, na medida em que essa exige um diálogo entre os estudos da globalização e a experiência da pesquisa etnográfica. Vemo-nos, dessa forma, diante do desafio proposto por Magnani (2002), o de administrar o olhar de fora e de longe com o olhar de perto e de dentro. Trilhando esse caminho, a primeira observação acerca do nosso olhar de perto e de dentro diz respeito à ressignificação local dessas discursividades étnicas. À medida que os sujeitos e os grupos se apropriam dessas discursividades para contar sobre a sua experiência na cidade, suas trajetórias e seus itinerários urbanos (Eckert e Rocha, 2005), transformam-nas em “narrativas étnicas”.

Dialogando com a literatura compreendemos a narrativa como uma estória que é contada, portanto, ela pressupõe a existência de um narrador. A narrativa informa fatos de um tempo e de um espaço e, assim como as personagens e o enredo, o narrador também dela participa (Gancho, 2000). Na perspectiva do seu uso na antropologia, a base referencial são os trabalhos de Eckert e Rocha (2005). Quando falamos, aqui, de narrativas étnicas, acrescentamos o étnico como um elemento importante na constituição das narrativas sobre a cidade.

As narrativas expressam contrariedades, tensões, emoções e fantasias cultivadas pelos sujeitos e os grupos nos jogos identitários e na prática do espaço. Através delas pode-se chegar à apreensão de como se conjugam os signos “locais” e "globais”, identificando nas estratégias locais as múltiplas formas de manifestação das identidades, de expressão do “diverso” e do “plural”. Os relatos sobre as cidades trazem à tona os sentimentos dos sujeitos frente às transformações - reais ou imaginárias - do espaço e das vivências coletivas.

Na demarcação das diferenças entre os indivíduos e os grupos há a sobreposição de algumas lembranças em detrimento de outras; todo o jogo de identidades envolve também silêncios, acontecimentos não-ditos, a propagação de mecanismos sutis que permitem a preservação de alguns elementos e o acobertamento de outros. É neste jogo, de afirmação e negação, que as identidades produzem e asseguram a força de suas narrativas míticas. 
Olhar a cidade sob o viés da “diversidade” pressupõe levar em conta as relações de poder que estão imbricadas nas formas de ocupação e apropriação dos seus espaços e nos jogos de produção da memória, ou seja, naquilo que é da ordem da seleção do que se quer esquecer, do que se quer lembrar, especialmente quando está em disputa a consolidação de uma memória oficial sobre a cidade.

As narrativas étnicas acionadas a partir das ações afirmativas competem no plano do imaginário ${ }^{10}$ com outras narrativas que versam sobre o espaço da cidade, confrontando, muitas vezes, uma memória socialmente constituída.

Nesta direção, cabe-nos destacar algumas leituras, como a de Waldo Ansaldi (2002), que acredita na existência de uma memória coletiva do poder e uma memória coletiva dos dominados. A memória do poder exerceria um controle sobre o passado, elegendo expressões simbólicas para representar as identidades e imaginários sociais resultantes da dialética entre esquecimento e memória. Essa memória-poder também é assinalada por Eckert (2002) ao se referir a uma memória oficial, erigida pelos Estados nacionais, memória inscrita linearmente, que nega as interrupções e descontinuidades do vivido.

Halbwachs, quando introduz o conceito de memória coletiva o faz para ampliar a concepção da memória para além da dimensão psicológica, isto é, enfatizando que a memória é um fenômeno social, resultado das relações que os indivíduos estabelecem entre si, pois tanto o lembrar quanto o esquecer tem uma dimensão coletiva. Naquele momento, Halbwachs já alertava para a distinção entre a "história aprendida e escrita” e a "história vivida”. A memória não é a simples sobrevivência ou conservação do passado, é, acima de tudo, imagem construída no presente que tem como suporte as experiências do passado (Halbwachs, 2006)..

Alguns grupos, ao clamarem por uma visibilidade racial e étnica, desestruturam práticas consolidadas e legitimadas pelo tempo: questionam as historiografias clássicas, propõem “contar

\footnotetext{
${ }^{10}$ Fazemos menção ao conceito de imaginário ressaltando alguns aspectos presentes na obra de Gilbert Durand, As Estruturas Antropológicas do Imaginário, especialmente quando o autor se refere à dimensão da expressão criadora que constitui o campo do imaginário. Ao denunciar a desvalorização cultural do imaginário no pensamento ocidental que, em nome da perseguição de uma "verdade” e de uma "objetividade” científica, pretendeu “desmistificar” a consciência, reduzindo o fenômeno humano à mera experiência da racionalidade, Durand faz a defesa de uma imaginação criadora, de uma fantástica transcendental capaz de resistir aos imperativos da história e ao "puritanismo racionalista” do ocidente. Portanto, para Durand, o imaginário não é tão somente o resultado das “intimações objetivas do meio cósmico e social”, não é mera representação da vida social e material; a matéria do imaginário pressupõe uma troca, uma gênese recíproca entre as pulsões subjetivas do indivíduo e as intimações objetivas. Assim, “o imaginário não é mais que esse trajeto no qual a representação do objeto se deixa assimilar e modelar pelos imperativos pulsionais do sujeito.” (Durand, 2002: 41).
} 
outra história” ${ }^{11}$, forjar memórias, (re) construir itinerários, (re) organizar sentimentos e valores coletivos.

\section{As comunidades negras e a memória coletiva}

Antes de discorrermos sobre as políticas de ações afirmativas e suas implicações no contexto urbano, especialmente na voz das comunidades negras ${ }^{12}$, queremos retomar algumas discussões que não são novas na sociedade brasileira, ao contrário, acompanham-na desde a sua formação, pois dizem respeito à segregação racial e étnica dos espaços das cidades. Essa retomada ajuda-nos a refletir sobre os paradoxos e contradições presentes numa lógica urbana que passa incorporar a ideia de diversidade.

Para realizar esse intento, iniciamos com a demarcação de alguns elementos. Primeiramente, lembramos que a partir da segunda metade do século XX deu-se início na sociedade brasileira a uma maior participação política dos chamados "novos sujeitos de direitos” - mulheres, negros, índios, homossexuais, entre outros. Ao mesmo tempo em que esses grupos passaram a fazer a defesa do uso da cidade, da apropriação dos seus espaços, do direito à territorialização, do respeito às suas experiências coletivas, continuou-se convivendo com os resquícios de uma lógica urbana segregacionista e racista. Não se pode esquecer que a edificação dos conjuntos urbanos no Brasil ocorreu paralelamente à propagação dos ideais liberais da racionalidade técnica e do progresso, ideais esses revestidos de uma concepção de eugenia e de limpeza étnico-racial.

Não são poucos os trabalhos que mostram a exclusão social e racial provocada pelas políticas urbanas no Brasil, desde o final do século XIX até o século XX. Muniz Sodré (1988) mostra os efeitos dessa visão sobre a ocupação dos espaços e a constituição de regras de segregação territorial, elegendo como locus privilegiado para a sua análise a cidade do Rio de Janeiro. No século XIX, as cidades brasileiras, sob o arbítrio dos interesses de seus administradores, foram palcos para a materialização de políticas urbanas "modernizantes”

${ }^{11}$ Fazemos referência à pesquisa de Magna Magalhães sobre os negros em Novo Hamburgo/RS, intitulada “Contando uma outra História: memória e identidade na Sociedade Cruzeiro do Sul”, da qual brotou o artigo “Negras Memórias: a trajetória da Sociedade Cruzeiro do Sul” (Magalhães, 2005).

${ }^{12}$ Optamos pela denominação comunidades negras por esta assumir característica de categoria êmica, fazendo parte da linguagem habitual dos moradores da cidade que, na sequëncia deste artigo, são transformados em narradores. Ademais, ao falar do movimento negro contemporâneo consideramos a heterogeneidade da sua configuração e as diferentes vozes que o constituem: sujeitos individuais e coletivos, associações, ONGs, comitês, organizações formais e não-formais. 
influenciadas pelas ideias de higiene e saneamento. Por intermédio das políticas higienistas e campanhas de vacinação construíram-se verdadeiros cordões sanitários que isolavam os pobres e os negros dos principais espaços de sociabilidade urbana. Somava-se a este movimento a proliferação das teorias raciais que colocavam o negro e o índio como empecilhos para o desenvolvimento do país. ${ }^{13}$

Se, por um lado, estas populações eram fundamentais para a realização do trabalho de edificação dos centros urbanos e a sua manutenção, por outro, representavam a própria inversão dos valores culturais idealizados por estas teorias. ${ }^{14}$ Além disso, estimulava-se a imigração de alguns grupos étnico-raciais europeus reforçando-se a crença na regeneração das "raças" por meio da mistura e da miscigenação.

Levamos em consideração esses elementos para afirmar que, hoje, quando falamos em ações afirmativas para as populações negras e indígenas no espaço urbano, não estamos falando apenas da adoção de medidas no campo da ação social, mas, sobretudo, que esses grupos começam a estabelecer disputas no plano do simbólico. Esses grupos propõem reconstituir sua história coletiva, dar visibilidade às suas memórias, projetar-se no âmbito de um imaginário coletivo, buscando romper com as valorações negativas que lhes foram atribuídas.

Porém, é preciso atenção no uso de alguns conceitos e teorias. Munanga (2006) alerta para a necessidade do uso crítico de conceitos como "etnia”, “diversidade”, "identidade cultural”, amplamente popularizados nas ciências sociais contemporâneas. Segundo esse autor, o racismo hoje não necessita mais do sentido biologizante do conceito de raça para se perpetuar. Ele se reproduz pela essencialização histórico-cultural. Estabeleceu-se um paradoxo porque racistas e não-racistas defendem a mesma bandeira das políticas multiculturais, fundamentadas nas diferenças culturais, étnicas e identitárias. Não são apenas os grupos historicamente marginalizados que se utilizam desses conceitos para fazer a defesa dos seus direitos, mas também aqueles que permanecem favorecidos pelas relações de dominação, que ainda fazem do discurso da diferença um mecanismo de reprodução da desigualdade.

\footnotetext{
${ }^{13}$ As teorias raciais ganharam força no país no final do século XIX. Para esta discussão, ver Shwarcz (1993).

${ }^{14}$ Muniz Sodré (1988: 39) sublinha como a cultura negra choca-se com o comportamento burguês europeu exatamente por colocar a liberdade corporal no centro do processo comunicativo, em contraposição à valorização do distanciamento dos corpos.
} 
Não basta, portanto, interrogar-se sobre quais são as implicações de se pensar a sociedade brasileira sob a lógica da existência de uma “diversidade étnico-racial ${ }^{15}$, o que se deve indagar é sobre o que esta ideia de diversidade étnico-racial, fortalecida pela expansão dos ideais multiculturais, pode desencadear no caso de haver algum nível de reconhecimento das distintas ${ }^{16}$ valorações atribuídas aos grupos étnico-raciais ao longo da formação da sociedade brasileira e, claro, a possibilidade da existência de medidas reparadoras que busquem alterar alguma realidade de exclusão.

Muniz Sodré, ao discorrer sobre a tradição do pensamento ocidental, lembra que a diferença liga-se ao “universal abstrato”, enquanto a diversidade liga-se ao "universal concreto”. Se o reconhecimento da diferença pauta-se por uma postura especulativa, racionalizada, de ordem intelectual, a passagem para uma verdadeira compreensão e aceitação do “diferente concreto”, que, no caso, seria a experiência da diversidade, exigiria mais do que o reconhecimento intelectual da diferença, mas um reconhecimento sensível. Por isso, não se pode descolar estes conceitos da noção de valor. “A percepção da diferença vai além do simples registro da variedade das aparências, porque o olhar, ao mesmo tempo em que percebe atribui um valor e, claro, determinada orientação de conduta.” (2006: 8). O mero reconhecimento intelectual da diferença não significa sua aceitação, tampouco colabora com a ruptura das práticas discriminatórias e as relações assimétricas. A diversidade humana precisa ser reconhecida na prática, no cotidiano, na convivência diária. É exatamente aqui que o autor acredita estar a grande contribuição do debate contemporâneo sobre a diversidade. De resto, o autor lembra que o simples reconhecimento da diferença cultural não impediu a dominação e subjugação de povos pelo colonialismo ocidental, desse “outro" tantas vezes inferiorizado por uma lógica racional que desrespeitou outras possibilidades de conhecimento e de vida humana.

Não podemos esquecer que a noção de diferença remete tanto à compreensão daquilo que é intrínseco aos sujeitos e aos grupos quanto àquilo que é construído no jogo das relações “entre” os sujeitos e os grupos. Pensar, portanto, a diferença na diversidade, é atentar tanto para as relações construídas “entre”, quanto para aquilo que é próprio da experiência de cada grupo, que é da dimensão do irredutível.

\footnotetext{
${ }^{15}$ Ortiz (1994), ao discorrer sobre o modo de perpetuação das teorias tradicionais na sociedade brasileira, afirma que a defesa da diversidade cultural é corrente entre intelectuais brasileiros desde a década de 60 .

${ }^{16}$ Neste caso, usamos distinção no sentido proposto por Bourdieu (1983), a fim de destacar a dimensão simbólica da diferença.
} 
A sensibilidade para experienciar o que é da ordem do "universal concreto" abre a possibilidade "real” da convivência com o “diverso”. O “diferente”, o “universal abstrato”, é transformado em “diverso” pela aceitação e proximidade. Para isso, faz-se necessário atentar para as duas dimensões desta diferenciação: os aspectos irredutíveis e os aspectos relacionais.

A experiência dos negros, quando comparada a outros grupos, não se pode igualar nem do ponto de vista do vivido, nem do ponto de vista da sua “distinção simbólica” (Bourdieu, 1983). É desta experiência particular que se parte, para se chegar, aí sim, àquilo que é da ordem da ação política, dos valores que podem ser questionados e alterados. Por isso, não se pode falar de diversidade sem fazer menção aos valores atribuídos no jogo relacional da diferença.

Verificar as implicações dessas discursividades sobre a ocupação e apropriação dos espaços da cidade requer uma análise crítica sobre o processo histórico de constituição do Estado nacional brasileiro, que ao negar a diversidade étnico-racial acomodou as manifestações do preconceito e do racismo no interior do discurso da desigualdade social. ${ }^{17}$ Interpretar a cidade na perspectiva da diversidade, privilegiando seus marcadores étnicos, sem contextualizar os jogos de poder presentes nessas práticas discursivas é correr o risco de atualizar as desigualdades étnicoraciais sob uma nova retórica.

No momento em que alertamos para a disseminação das discursividades étnicas nas cidades contemporâneas, enumeramos algumas indagações: o que está sendo eleito, hoje, para demarcar a “diferença”? Que “identidade cultural” as cidades estão mobilizadas para revitalizar? Ao se eleger uma singularidade cultural como representativa, quais outras estão sendo invisibilizadas?

Uma parte das respostas às nossas indagações pode ser encontrada na leitura das políticas do patrimônio. Rogério Proença Leite (2004) analisa a vinculação histórica das políticas do patrimônio com a construção de uma determinada narrativa de nação. O autor mostra como durante o Estado Novo a concepção oficial de cultura alinhou-se ao discurso do chamado “caráter nacional” e à busca de uma originalidade brasileira, sintetizada naquele momento pelo legado barroco de Minas Gerais. Seguindo esse raciocínio, o autor vai demonstrando o quanto essas políticas - hegemônicas no período de 1938 a 1981 - estavam comprometidas com os valores representativos de uma etnia branca, católica e com o poder de Estado. Se as políticas do

${ }^{17}$ Sobre a negação do racismo e do preconceito na sociedade brasileira, ver obra clássica de Florestan Fernandes (2007). 
patrimônio estavam mobilizadas para reforçar o lugar simbólico da nação e edificar uma “memória nacional”, o autor constata uma alteração nessa tendência, especialmente a partir dos anos 70, quando se desloca o foco da nação para as cidades. Essas políticas passam, então, a preocupar-se com o desenvolvimento econômico das cidades históricas, acentuando-se essa tendência na década de 90, com as políticas de gentrification que estimulam a "concorrência intercidades” (Leite, 2004: 61).

Rogério Proença Leite (2004) alerta para a marginalidade do chamado "patrimônio imaterial” nos projetos que visam a valorização dos bens culturais da cidade. O autor informa que apesar de a discussão ser fomentada na década de 70, por pesquisadores ligados ao Centro de Referência Cultural, que defendiam a ligação entre desenvolvimento e identidade cultural, somente em 1997 essa proposta é retomada pelo Instituto do Patrimônio Histórico e Artístico Nacional (IPHAN).

Devemos nos perguntar como essas políticas na contemporaneidade podem garantir os direitos dos diferentes grupos que habitam a cidade, por meio da construção efetiva de uma cidadania plural, que valorize os bens culturais de todos, não apenas de uma parte da população, sob pena de se perpetuar a exclusão social com um discurso "politicamente correto”, que seleciona as “identidades” e “diferenças” a fim de exibi-las em cenários montados para tal propósito.

A antropologia e os estudos da memória coletiva esforçam-se para buscar algumas respostas a esses questionamentos. Por exemplo, é o que diz Jeudy (1990), que, mesmo sabendo dos limites da disciplina, acredita que a “etnologia” pode ser o fio condutor para a compreensão das funções sociais da memória, por meio de uma formulação crítica da própria noção de patrimônio, superando uma visão puramente monumental. Ao mesmo tempo, o autor alerta para o fato de que a etnologia pode cair num idealismo ingênuo, ao crer na possibilidade de uma (re)constituição de uma memória plural do social. De qualquer forma, a grandeza da análise de Jeudy reside exatamente na constatação dos movimentos das memórias e das identidades culturais nas atuais políticas do patrimônio e de que esta multiplicidade, presente nos jogos da memória, é objeto da etnologia.

Se as políticas do patrimônio têm sido devidamente influenciadas pelos movimentos identitários contemporâneos, o que, para Jeudy, vem causando uma “objetalização da cultura”, vale a pena refletir sobre a influência dessas discursividades quando se trata de pensar aqueles 
grupos que estiveram afastados do poder político e econômico por ocasião da formação dos Estados nacionais. No caso brasileiro, vale a pena atentar para os desdobramentos das políticas de ações afirmativas no que se refere à cidade e a democratização dos seus espaços. Trata-se de observar os dois movimentos, tanto o de defesa do patrimônio material quanto o que reivindica atenção para o patrimônio imaterial.

Uma política de valorização dos bens culturais intangíveis de uma cidade deve abarcar os fazeres e saberes dos diferentes grupos que a constituem. Só assim é possível alcançar-se uma gestão democrática da cidade, respeitando-se e valorizando-se o seu caráter polissêmico, as múltiplas linguagens que fazem dela muito mais do que um conjunto de prédios, casas e monumentos, mas o lugar das expressões subjetivas dos sujeitos, das emoções partilhadas, de um "querer viver coletivo." As cidades podem incorporar nas políticas de preservação dos bens culturais os chamados bens imateriais ou intangíveis dos diferentes grupos, isto é, não só os bens de ordem material, como objetos, arquitetura, monumentos, mas também aquilo que é da ordem do saber cotidiano, como os modos de vida e as práticas sociais.

Percebemos que já se vislumbra nas cidades brasileiras um movimento de defesa e reconhecimento das produções culturais afro-brasileiras como constituintes dos novos patrimônios, movimento esse que vem se acentuando com as chamadas políticas de ações afirmativas.

\section{Etnografando as narrativas étnicas na cidade de Novo Hamburgo}

A partir de registros etnográficos originários de uma pesquisa ${ }^{18}$ realizada com as comunidades negras do município de Novo Hamburgo, no Vale do Rio dos Sinos/RS, ${ }^{19}$ Brasil, analisamos como os sujeitos e os grupos recorrem a narrativas étnicas para definir lugares de pertencimento e se inserem num jogo de disputa de memórias sobre o espaço da cidade,

\footnotetext{
${ }^{18}$ Algumas narrativas podem ser analisadas na íntegra na tese "O negro no mundo alemão" (Nunes, 2009), pois foram gravadas por ocasião da pesquisa de campo para o Doutorado. Ali, o leitor pode ter acesso às narrativas de interlocutores negros e não-negros ouvidos durante a pesquisa.

${ }^{19}$ Segundo a Fundação de Economia e Estatística do Rio Grande do Sul (FEE/RS), o Conselho Regional de Desenvolvimento do Vale do Rio dos Sinos (COREDE Vale do Sinos), abrange hoje catorze municípios. São estes: Canoas, Esteio, Sapucaia do Sul, São Leopoldo, Novo Hamburgo, Estância Velha, Ivoti, Dois Irmãos, Campo Bom, Sapiranga, Portão, Nova Hartz, Nova Santa Rita e Araricá. A população total do Vale (2007) corresponde a 1.273 .582 habitantes. Possui uma área de 1.398,5 $\mathrm{Km}^{2}$ e uma densidade de $903,1 \mathrm{hab} / \mathrm{Km}^{2}$ (2007). O índice de analfabetismo é de 4,80\% e a expectativa de vida ao nascer é de 71,76 anos. PIB per capita (2005) de R\$ 17.409. A estimativa populacional do município de Novo Hamburgo é de 253.067 habitantes (2007); possui uma área de 223,6 $\mathrm{Km}^{2}$ e uma densidade demográfica de 1.120,9 hab/ $\mathrm{Km}^{2}$. A taxa de analfabetismo é de 5,01 \% e a expectativa de vida é de 70,12 anos. PIB per capita (2005) de 14.595.
} 
colocando em xeque teorias tradicionais (Ortiz, 1994) sobre a identidade local, regional e nacional. Para isso, nos utilizamos da etnografia da duração (Eckert e Rocha, 2005) a fim de compreender as narrativas étnicas e as disputas de poder inerentes aos jogos da memória.

Salientamos que essas narrativas étnicas ganham força e legitimidade a partir da tradução local das políticas de ação afirmativa, especialmente por meio da ação do movimento negro. Essas narrativas étnicas, por sua vez, competem no plano do imaginário com outras narrativas que versam sobre o espaço da cidade e o vinculam à memória da imigração alemã no Vale.

No século XVIII, muito antes da chegada dos alemães, a região hoje conhecida como Vale do Rio dos Sinos já era ocupada por portugueses, açorianos e seus descendentes, africanos e descendentes de africanos e, evidentemente, por povos indígenas, especialmente os kaingang, mais conhecidos no período por coroados ou bugres. ${ }^{20}$ Porém, as narrativas que versam sobre o Vale do Sinos fazem do ano de 1824, data da chegada das primeiras famílias alemãs, o grande marco para a edificação de uma memória oficial sobre a região.

A memória erigida pela historiografia oficial põe em relevo a saga do imigrante, sua coragem e a força do seu trabalho como estopins para o desenvolvimento econômico do Vale. As narrativas históricas, literárias e as práticas discursivas locais costumam unir etnicidade alemã e desenvolvimento econômico. Essa visão é bastante questionada pelo movimento negro local, que diz serem os negros co-responsáveis por este desenvolvimento, na medida em que desde o início da industrialização foram braços fortes no trabalho das fábricas, especialmente nos curtumes.

Deve-se considerar que mesmo antes da industrialização, ainda no século XIX, a edificação dessas cidades contou com a força do trabalho escravo, ${ }^{21}$ contrariando a afirmação de parte da historiografia que exclui ou diminui a importância da escravidão nas regiões de colonização alemã. Isto é o que revela, por exemplo, as pesquisas da historiadora Eliege Moura

\footnotetext{
${ }^{20}$ Sobre os bugres há alguns relatos curiosos, como o de Leopoldo Petry, publicado em 1923: "Viviam em pequenos bandos nos mattos virgens de toda a zona que se estende ao norte do Rio dos Sinos, esperando ocasião para poderem roubar. Costumavam rondar por muito tempo os estabelecimentos mais avançados dos colonos e quando lhes parecia opportuno, assaltavam-no, matavam os homens, raptavam as mulheres e levavam consigo utensilios que podiam carregar. Depois retiravam-se para o interior da mattas donde só depois de muito tempo tornavam a voltar (...) Entre esses bandos se destacava o do famigerado João Grande, um escravo fugido, que tinha um odio ferrenho á população branca. Tinha elle reunido em torno de si varios bugres, entre elles, um genro do cacique Dobre com sua família.”(Petry, 1923:32). Nota-se que Petry faz alusão à aliança entre escravos fugitivos e bugres.

${ }^{21}$ Günter Weimer, ao discorrer sobre os engenheiros e arquitetos alemães no Rio Grande do Sul, sublinha que a mão de-obra das edificações era basicamente escrava. Tanto quanto os lusos, os alemães usavam de muita repressão no trato com os escravos. Ver Weimer, in: Müller (1980).
} 
Alves (2005) que dedica uma atenção especial ao período delimitado entre os anos de 1850 e 1870, identificando a presença escrava e analisando a sua importância na colônia alemã de São Leopoldo/RS.

A invisibilidade do trabalho escravo, ou até a sua negação, em boa parte da historiografia sobre a região, contribuiu sensivelmente para disseminar e legitimar representações e imagens do Vale do Sinos associadas ao “progresso e à civilização”.

Desde a sua emancipação política, em 1927, quando se separa definitivamente do município de São Leopoldo, Novo Hamburgo busca firmar-se como a cidade do “progresso” e do “desenvolvimento", com uma economia marcadamente industrial, especialmente de base coureiro-calçadista.

Ao longo do século XX, Novo Hamburgo conquistou um lugar de destaque na manufatura de calçados, tanto para o abastecimento do mercado externo quanto para o mercado interno. A partir da década de 90, a centralidade do município para a economia regional começa a ser ameaçada por causa de uma série de fatores, entre eles está a concorrência com o mercado chinês. Muitos destes elementos aparecem direta ou indiretamente nas narrativas biográficas de alguns interlocutores. O tempo do apogeu e o tempo da crise da indústria calçadista são constantemente evocados, entrelaçam-se ao relato das trajetórias sociais desses sujeitos.

A ruptura com o discurso da invisibilidade da presença e da contribuição dos negros na cidade e na região pressupõe uma escuta das narrativas dos sujeitos que estiveram diretamente envolvidos na edificação do “trabalho” e do “desenvolvimento” no Vale, mas que, mesmo sendo agentes diretos desse fazer, ficaram no anonimato.

Formei-me no curso primário, em uma escola municipal, e na época em que fui fazer o segundo grau, era o ginásio, na Escola 25 de Julho, escola estadual. Estudei lá até os 12 anos, aí eu rodei e fui trabalhar com 12 anos. Precisava trabalhar. Comecei trabalhando numa fabriqueta que fazia sapatos, sapato popular, passava cola, passava tinta, onde meus irmãos já trabalhavam. Lá pelos meus 15 anos eu resolvi terminar o ginásio, que eu tinha rodado aos 12 anos. Fui fazer um supletivo e, aos 18 ou 19 anos, terminei o ginásio. A essas alturas eu continuava trabalhando numa fábrica de sapatos e continuava fazendo as mesmas coisas. Como eu senti que era aquilo realmente que eu tinha que fazer, que era fazer sapato, toda a economia da região era à base de sapato, eu resolvi fazer um curso profissionalizante. Foi quando eu fiz um curso de modelagem de calçado, inspirado por um gerente que eu tinha, que estava sempre fazendo modelo. Ali foi que alavancou um pouquinho a minha condição de vida, porque o modelista já tinha uma posição mais destacada na empresa, já ganhava um pouquinho mais. Comecei nessa mesma empresa a fazer uns modelinhos meio simples, mas comecei (...) Dali, terminando esse curso profissionalizante dentro da área, eu resolvi fazer um curso técnico em calçado, quis aumentar meus conhecimentos, em nível de segundo grau. Mesmo antes de me formar - naquela época o mercado exigia muito profissional, pois tinha pouquíssimo profissional para a demanda de trabalho - antes de terminar o curso 
técnico eu já tinha sido contratado por uma outra empresa, com um ótimo salário, acho que ganhando umas cinco ou seis vezes mais do que eu ganhava até então. Foi quando eu fui trabalhar em Campo Bom. Até então eu tinha trabalhado só em Novo Hamburgo. Fui então trabalhar em Campo Bom, num grupo muito forte, onde trabalhei por 3 anos. Tinha, então, 22 anos. Aí casei, a minha namorada ficou grávida, eu era noivo, e naquela época a coisa era mais séria do que é hoje: “fez? tem que assumir”. E a gente assumiu, a gente casou, e com 22 anos eu estava casado e com trabalho em Campo Bom, com um emprego bem mais rendoso. Praticamente, a profissão que eu exerço até hoje foi aprendida naquela época, foi dedicação minha daquela época, já que eu estava naquele mercado eu senti a necessidade de me preparar um pouquinho mais, pra poder também ter recurso melhor pra viver. De lá, dessa empresa de Campo Bom, eu fui contratado pra trabalhar numa companhia de exportação. Na época começou o boom de exportação de calçados para os Estados Unidos, e eu fiz um trabalho muito bom dentro dessa empresa. Em 1975... trabalhei até 1983 nessa empresa. E pela necessidade deles prepararem a gente para o mercado exportador, logo fui fazer viagens para o exterior, já me envolveram direto em todo o mecanismo da exportação. Eu fui empregado como técnico e modelista, responsável tanto pela área técnica como pela área de desenvolvimento de produto, e ali trabalhei 8 anos. A empresa aumentou mais ainda meu salário, eu estava ganhando quase o dobro do que eu ganhava antes, aí a minha vida profissional teve um crescimento em nível de salário bom, porque na época eles pagavam em dólares, então a gente ganhava bem, dinheiro suficiente pra viver uma classe média legal. Até então, não tinha percebido nenhum tipo de discriminação em relação a eu ser negro, porque parecia que o mercado de trabalho olhava muito mais o lado profissional do que na realidade essas questões de preconceito. Mesmo nas viagens que fiz para o exterior eu nunca senti nenhum tipo de discriminação, pois nessas viagens aparecem muitos tipos de etnias, de todas as raças e cores. Depois que saí dessa empresa, logo fui contratado por outra exportadora, onde trabalhei por mais 7 anos. Essa empresa fechou e eu fui me dedicar ao mercado interno. Abri uma empresa de desenvolvimento que não deu muito certo, aí acabei sendo contratado por uma empresa pra trabalhar também no mercado interno. Fui contratado pra ser gerente da área de desenvolvimento. Ali eu senti o primeiro sinal de discriminação, em 1990. Tinha então 40 anos de idade, estava com o diretor dando uma volta pelo setor, passei por outro setor auxiliar e uma pessoa falou nas minhas costas: "O que é que este negão quer aí?” Eu não sei se o meu diretor ouviu, eu sei que eu escutei e fiquei calado, porque, na realidade, aquela pessoa que falou a partir daquele momento era meu subordinado. Então, eu senti que mesmo que ele tivesse tido alguma idéia errônea a meu respeito com o tempo iria desaparecer porque eu teria que tratar ele de igual pra igual. Realmente, com o tempo a gente teve uma adaptação muito boa no trabalho e essas questões se dissiparam, não foi uma coisa que ficou marcada, a gente comenta porque tem muita discriminação ainda, em geral a respeito de preconceito, mas eu não levei muito a sério, levei como uma reação momentânea daquela pessoa. Nessa empresa fiquei por 3 anos. Ali eu fui pela primeira vez à Europa, fiz pesquisa de moda e realmente minha influência profissional sempre foi muito bem vista no Vale (Valdemar, mar. 2008. Entrevista gravada).

Nota-se como na narrativa de Valdemar ele aciona o valor trabalho como um elemento balizador da sua trajetória individual (Velho, 1994). Ele foi um expoente do processo de exportação do Vale: estudou, trabalhou, buscou qualificação, viajou para o exterior, "ganhou bem”, fez pesquisa de moda, foi "reconhecido”. Seu projeto individual somou-se a um projeto coletivo (Velho, 1994) de desenvolvimento do Vale. Na sua narrativa, o tempo de abundância do trabalho foi o tempo da invisibilidade da discriminação racial. À medida que os postos de trabalho foram escasseando o preconceito passou a ser externalizado, veio à tona. Pode-se 
acrescentar a isso o fato de que, naquele momento, as discussões relativas à discriminação e preconceitos raciais, as propostas de políticas públicas para as populações negras, tinham menor visibilidade do que a partir dos anos 90 .

Esta relação entre a “crise” do emprego e a percepção da discriminação racial é assinalada também por Jaime:

Não tive o privilégio de ter meu estudo por que tive que trabalhar cedo, me orgulho da profissão que trabalhei e, por isso, minha aposentadoria começou cedo porque sempre trabalhei com carteira assinada, 30 anos na carteira, de serviço, e com 47 anos já estava aposentado. (...) Naquela época não era tanto... fui sentir a discriminação...é... quando cheguei na empresa (...), em 1992. Cheguei a pegar na empresa....De 170 empregados eram só 3 (três) negros na empresa.... mas a gente não era discriminado por eles, se sentia discriminado no período de festas de fim de ano e nas outras festividades... todos... e só nós negros no meio de 170 empregados.

(...)Na época, (do calçado) a gente chegava a ter um time de futebol de negros dentro da empresa, tinha mais ou menos 11 (onze) negros dentro da empresa. O Requinte tinha o hábito de trazer negros de fora por causa de time de futebol. (...) O meu tio era gerente do Requinte, daí ele começou a trazer... Viemos parar aqui em Novo Hamburgo por causa dele. Ele foi gerente do Requinte e trouxe os cunhados dele para trabalhar aqui. Eu sou de Santana do Livramento. Lá não tem serviço, só serviço na lavoura, firma não tem pra lá. Então ele era gerente do Requinte, trouxe os cunhados para trabalhar e formar um time, para jogar bola...um time de futebol. Trouxe todos meus tios, 3 (três), 4 (quatro), e assim começou tanto que toda a minha família trabalhou no Requinte. (...) Meu tio era gerente, foi um dos primeiros negros metidos a besta assim... Minha tia dizia que ia espetar ela para ver se ele tinha sangue azul porque não podia ser vermelho, ele era muito diferente. (risos).(Jaime P. da Silva, mar. 2008. Entrevista gravada).

De novo, o valor-trabalho aparece como um elemento importante para a afirmação identitária. Iniciar cedo no mundo do trabalho, aposentar-se com “30 anos de carteira” são qualidades abonadoras na narrativa de Jaime. Também fica explícita na narrativa de Jaime a ideia de que uma das formas que os negros encontraram para acessar o mundo do trabalho foram as participações nos times de futebol. Quer dizer, os negros eram vistos como bons no futebol, por isso eram buscados para trabalhar em determinadas empresas. Jaime contou que a partir de 1992 passou a trabalhar em outra empresa, fora do ramo coureiro-calçadista, essa praticamente não contratava negros, portanto, não havia mais a sociabilidade de outrora mediada pelo futebol, foi quando se deu conta da discriminação.

Os negros, ao lado de outros grupos, como os chamados pêlos-duros, ${ }^{22}$ foram protagonistas anônimos da industrialização do Vale. Se não foram os detentores do capital, foram os produtores diretos da riqueza extraída da força de trabalho. Hoje, uma parcela desta população

\footnotetext{
${ }^{22}$ Expressão local para designar os indivíduos que descendem da mistura de portugueses ou espanhóis com índios.
} 
vê-se forçada a migrar ou, então, vivencia uma precarização das relações de trabalho, cujo reflexo imediato é a acentuação da violência e da criminalidade urbana.

No cenário da globalização econômica, em que Novo Hamburgo deixou de ser o cluster do calçado e uma parte do capital, das empresas e, até mesmo, da força de trabalho, migraram para outros lugares, resta perguntar: “Como ficaram os negros neste processo?”, “Quando se pensa em políticas de ação afirmativa no Vale e na cidade, quais as implicações destas questões econômicas para os homens e mulheres negros?”

Exatamente no momento em que se dá maior visibilidade à discussão das políticas de ação afirmativa na sociedade brasileira, as possibilidades de ascensão social tornaram-se mais distantes destas populações do Vale.

Cabe ressaltar que em várias cidades do Vale recorre-se à etnicidade alemã como recurso para dinamizar a economia. Por trás da proliferação das "festas étnicas” há o interesse de desenvolver o turismo e estimular uma "cultura de consumo", através da expansão dos espaços de lazer e de diversão.

Sassen (1998), no livro As cidades na economia mundial, destaca que muitas cidades e centros manufatureiros perderam suas funções nesta atual fase de expansão e organização do capital, pois houve um deslocamento de investimentos do setor manufatureiro para o setor financeiro e o de prestação de serviços. Essa leitura ajuda-nos a situar a cidade de Novo Hamburgo dentro dos processos globais, especialmente econômicos. Em uma das passagens de seu livro, A cidade concentra a diversidade, a autora oferece-nos uma brecha para pensarmos o quanto os processos de globalização são chaves para a compreensão das transformações dos jogos interétnicos nas cidades brasileiras.

Neste caminho, a leitura de Jeudy (1990) também presta-nos grande auxílio, pois a partir da sua crítica à "objetalização da cultura” e à teatralização da memória”, podemos constatar a força da etnicidade nas configurações estéticas das cidades contemporâneas e a sua importância para este movimento de "teatralização das memórias".

A memória coletiva também passa a ser valorizada como um modo de dar voz àqueles que hoje reivindicam direitos ao espaço da cidade, à visibilidade de suas expressões culturais, ao acesso de bens e serviços disponibilizados no meio urbano.

Halbwachs (2006) alerta para os contextos sociais de produção da memória. As lembranças de um tempo e um espaço partilhados socialmente são as matérias-primas para a 
edificação das memórias individuais e coletivas. São também esses quadros sociais que balizam a elaboração de uma memória histórica, isto é, a reconstrução do passado por meio da história escrita, o que, para Halbwachs (2006), distancia-se da história vivida. O que é da ordem do vivido encontra suporte nas memórias individuais e coletivas.

Herdeiro de Durkheim, Halbwachs reforça a subordinação do individual pelo coletivo, quer dizer, só é possível falar-se da existência de uma memória individual se esta estiver entrelaçada a uma memória coletiva. É o meio social e as percepções da vida material que acionam esta memória individual. Os outros indivíduos, os objetos, os lugares, os elementos externos são fatores decisivos para o ato de lembrar. Além disso, se a percepção da duração não é compartilhada de modo igual por todos, ainda assim, existe a sensação de um tempo partilhado socialmente, um tempo coletivo. Por isso, os objetos e os lugares são trazidos para o jogo da memória, porque são eles que concedem a sensação de permanência e estabilidade às coisas desse mundo.

\footnotetext{
${ }^{23}$ Sobre o bairro África encontramos os seguintes registros no Semanário 05 de Abril: Anno 1, n.16 - 19 de agosto de 1927, "Vende-se uma pequena chácara bem arborisada, com uma casa de madeira, por preço baratissimo, situada á chácara do Snr. Adolfo Jaeger, no logar denominado Africa. Para tratar na mesma com o proprietário. Jacob Bier”; Anno VIII - 15 de junho de 1934, n.07, “Conflicto occorido hontem: fomos informados que um prêto, de nome Ernesto, e que se dedica à profissão de poceiro, e apezar de faltar-lhe uma perna, foi ferido hontem por um tal Francisco Marcellino no arrebalde denominado África, ferimento este produzido por projectil de arma de fogo, que foi alojar-se na outra, aliás na única perna que o infeliz Ernesto ainda possue (...)” Shütz (2001) informa que a alteração do nome África para Guarani ocorreu em 1943.
} 
(...) Novo Hamburgo era tratada como a capital, cidade do calçado. Cidade do Calçado! As pessoas vinham lá de fora, todo mundo se instalar em Novo Hamburgo, porque aqui eles iam ganhar dinheiro. O que é Novo Hamburgo hoje? Dá uma tristeza de ver. Essas firmas tudo com as portas fechadas. (Clarice, escola de samba Portela do Sul, 2006)

Em todas as narrativas confrontamo-nos com tempos superpostos: é o "tempo do calçado", o “tempo do trabalho”, que se justapõe ao "tempo da crise”, o "tempo do fechamento das fábricas”. A memória social do trabalho, as referências construídas no período do "auge” do calçado perduram no tempo, são elementos vivos nas narrativas.

Eckert (1993), no seu trabalho entre os mineiros grand-combianos, da cidade de La Grand-Combe, no sudeste da França, narra os impactos e sofrimentos de uma comunidade de trabalho de extração de carvão que se vê obrigada a se reorganizar por decorrência do fechamento das minas e da recessão econômica. O título Ritmos e ressonâncias da duração de uma comunidade de trabalho fala por si só. Ali, a autora fala desses tempos vividos e pensados como superpostos, como um movimento dialético de continuidades e descontinuidades. Eckert nos lembra que "se a vida social se transforma, ela continua, ela não é somente ruptura. Sobre esta, outra ordenação é pensada, exprimindo o ritmo dos esforços humanos em construir um devir que não será jamais oposição ou contradição ao passado e ao presente, mas superposição temporal num movimento ondulatório, no perpétuo recomeçar social.” (p.06).

A industrialização, o mundo do trabalho, é um lugar de ancoragem de uma memória oficial em Novo Hamburgo. Neste caso, é um dos quadros sociais onde a memória está registrada. Hoje, é deste universo que se selecionam imagens de Novo Hamburgo capazes de fazê-la permanecer no tempo.

Nesta memória social legitima-se a etnicidade alemã, atribuindo-se um sentido comum a um território compartilhado por grupos com referências étnico-raciais distintas ao longo do tempo. Nesta memória de um mundo alemão não desaparecem apenas os negros, os índios, os descendentes de portugueses e espanhóis, também desaparecem os alemães pobres, os que precisaram migrar para outras colônias e outros estados, os que não foram bem sucedidos com a industrialização da cidade. Há diferentes escalas e planos neste jogo de esquecimentos e lembranças que constituem as tramas da memória social, das memórias coletivas e das memórias individuais.

Ao falar das possibilidades da memória, Halbwachs (2006) não se detém na análise dos jogos de poder inerentes à constituição de uma memória histórica, nem dos tensionamentos 
resultantes do confronto das memórias coletivas, pois se existem vários pontos de encontro nas memórias de diferentes grupos que compartilham de um mesmo espaço social, existem os “pontos de fuga”, aquilo que os singulariza, que dá a sua experiência um caráter de “distinção” (Bourdieu, 1983).

É por isto que o trabalho de Jeudy (1990), Memórias do Social, torna-se, aqui, tão relevante. Nele buscamos elementos para compreender as relações de poder presentes na cena das cidades contemporâneas, onde o social é transformado em objeto da cultura, onde as chamadas “identidades culturais” disputam as políticas de representações do patrimônio, onde toda a vida social tem a chance de se colocar como "objeto de conservação”, onde a escolha do que vai ser consagrado não se limita mais ao “passado", ao "luto” e à “morte”, mas também se liga à teatralidade cotidiana que é chamada a participar deste jogo de valorização das memórias coletivas. O próprio antropólogo (a) está a serviço deste processo dinâmico de construção de memórias compartilhadas.

Os modos de vida que se ligam a uma Novo Hamburgo industrial alimentam o imaginário histórico. Exemplos ilustrativos são os relatos de alguns empresários e trabalhadores calçadistas no Vale, apresentados na obra Memória do Setor Coureiro-Calçadista: pioneiros e empreendedores do Vale do Rio dos Sinos. ${ }^{24}$

Deve-se acrescentar que se estas memórias do social em Novo Hamburgo alimentam a história escrita, elas também participam do interior das memórias coletivas dos diferentes grupos e, inclusive, de uma memória coletiva rio-grandense. Por isso, a proposta da etnografia da duração (Eckert e Rocha, 2005) ajuda na compreensão de como na narrativa biográfica dos sujeitos da pesquisa são estabelecidas conexões entre elas, à medida que eles experienciam a cidade, o trabalho em Novo Hamburgo, a ascensão social, o momento de queda dos postos de trabalho, as desigualdades pautadas nas diferenças étnico-raciais, o preconceito e discriminação raciais. As memórias coletivas estão o tempo todo dialogando com as memórias do social, que nutrem as discursividades e as narrativas étnicas sobre quem são os atores deste cenário do trabalho, do desenvolvimento, do progresso.

As discursividades étnicas ajudam a compor o cenário das disputas políticas e culturais das cidades contemporâneas, e trazem à tona o relato das experiências étnico-raciais distintas que marcaram a ocupação do espaço urbano ao longo do tempo, traduzidas e reconhecidas por meio

\footnotetext{
${ }^{24}$ Organizada por Schemes, C., Prodanov, C., Thön, I., Perla, R. (2005).
} 
das narrativas e dos itinerários dos seus habitantes (Eckert e Rocha, 2005) ${ }^{25}$. Imagens que remetem a outro tempo e a um outro espaço são acionadas para explicar e interpretar o lugar dos sujeitos e dos grupos no cenário do espaço urbano.

Existem bairros que eram bairros tradicionais de população negra, mas hoje é muito disseminado. Têm regiões que não eram tão tradicionais, tipo bairro São Jorge, que hoje tem uma população negra expressiva. Rondônia, talvez mais do que aqui (Primavera). Hoje na cidade é muito disseminado. Existe a questão da tradição: "tradicionalmente esse bairro..." onde estão as escolas de samba. No Guarani, ali tradicionalmente era denominado África, hoje é muito disseminado. O que ocorre... a Vera Triunfo que gosta muito de comentar, usar muito este termo, essa formação dos “quilombos urbanos”. De certa forma, são quilombos. O valor da terra aumentou muito a exploração imobiliária. Daí o que ocorre? As famílias têm um terreno, vai-se juntando, vai-se construindo uma casa nos fundos, no meio, não sei o quê, mas isso de uma forma muito disseminada. São grandes famílias, não são grandes grupos, mas grandes famílias que estão num local, em outro local, em outro local. Daí dá essa aglomeração muito urbana. (Mauro José da Silva - Comitê Pró-Ações Afirmativas de Novo Hamburgo, 2006. Os grifos são meus).

As discursividades do movimento negro criam ancoradouros para a edificação de uma memória social. Tornam-se falas oficiais representativas de um segmento, ainda que não hegemônicas e não legitimadas pelas instâncias do poder político dessas cidades. Nos relatos dos interlocutores negros ligados ao movimento social, essa memória social entrelaça-se à memória individual e à memória coletiva. Diferentemente da memória coletiva que não tem um autor definido e, portanto, entrelaça-se às histórias individuais dos sujeitos, a memória social demarca uma autoria, que pode ser um estado, uma nação, uma classe social, um movimento social etc. Em qualquer um dos casos, são narrativas que modulam diferentemente o tempo. A etnografia da duração (Eckert e Rocha, 2005) busca apreender a memória coletiva, a memória não oficializada, latente, anônima, sem dono, mas que está em permanente diálogo com as memórias do social (Jeudy, 1990).

Para não serem mais uma vez alijados dos processos econômicos, as populações negras do Vale do Sinos iniciam uma disputa no plano do simbólico, ao proporem a "reconstituição” da sua "singularidade cultural” e a inserção das suas expressões culturais na discussão dos novos patrimônios (Jeudy, 1990). Essas ações locais primam pela visibilidade da história vivida pelos negros no Vale dos Sinos, pela valorização dos seus espaços de sociabilidade, pela vinculação

\footnotetext{
${ }^{25}$ Para esta reflexão ver o documentário Os Caminhos Invisíveis do Negro em Porto Alegre: A tradição do Bará do Mercado, dirigido por Ana Luiza Carvalho da Rocha. O documentário mostra a luta pelo reconhecimento do Mercado Público de Porto Alegre como espaço identitário dos praticantes das religiões afro-brasileiras da cidade. O documentário, lançado em 2007, teve o apoio do Programa Petrobrás Cultural.
} 
dos homens e mulheres negros às narrativas que exaltam o "trabalho" e o "desenvolvimento" local como marcas da região.

A Sociedade Cruzeiro do Sul, uma das mais antigas da região, desde 2006 integra um coletivo constituído por clubes, agremiações e sociedades de negros do Rio Grande do Sul. Assumindo um caráter mais regional devido às dificuldades de agregar clubes mais distantes, a idéia de formação do coletivo surgiu depois de um encontro nacional de clubes e sociedades negras, que ocorreu em Santa Maria/RS. Este foi o I Encontro Nacional de Clubes e Sociedades Negras do Brasil, e ocorreu de 24 a 26 de novembro de 2006. O Encontro foi uma iniciativa da Secretaria Especial de Políticas de Promoção da Igualdade Racial do governo federal e, na época, contou com a presença da então ministra Matilde Ribeiro. Do Encontro resultou a Carta de Santa Maria que, dentre outras deliberações, primou pela reivindicação de políticas públicas para o reconhecimento dos clubes e sociedades de negros como patrimônio histórico e cultural dos afrobrasileiros.

A iniciativa de criação do Coletivo - CCFNR-RS ${ }^{26}$ - surgiu com o propósito de fortalecer as sociedades, inclusive financeiramente. Cada sociedade integrante realiza uma festa anualmente e, nesta data, as demais garantem um público mínimo de participantes, pois organizam-se antecipadamente com transporte, venda de convites etc. Articula-se, assim, uma rede de fortalecimento da solidariedade étnico-racial que se apresenta também como uma alternativa de sustentação financeira para esses clubes. Além das festas, o coletivo realiza reuniões periódicas. Por enquanto, integram este coletivo as seguintes entidades: a Sociedade Cruzeiro do Sul, de Novo Hamburgo, a Sociedade Négo, de Venâncio Aires, as Sociedades Castro Alves e Rui Barbosa, ambas de Canoas, e a Sociedade Floresta Montenegrina, de Montenegro. Sobre o coletivo, Ademir fez o seguinte relato:

(...) Logo no começo eu não levei muita fé, fiquei mais... fiquei meio de lado. Mas depois voltou e voltou um pouco mais forte: “Ademir, vamos fazer uma reunião?” A primeira reunião, inclusive, foi na Cruzeiro. Nessa reunião a única Sociedade que não se fez presente foi a Négo lá de Venâncio Aires. Daí fizemos a primeira reunião pra gente se unir mais. O que estava acontecendo? As Sociedades de negros do Brasil, do Rio Grande do Sul estavam diluídas, o pessoal não estava mais conseguindo fazer festa. E isto é uma coisa que eu até digo, agora, que a gente está conversando, que não são só as sociedades negras que estão com problemas, as sociedades brancas também estão com problemas: A Ginástica, a Atiradores... ${ }^{27} \mathrm{O}$ grande problema até não é financeiro. Dizem

\footnotetext{
${ }^{26}$ A sigla remete ao nome das sociedades envolvidas: Cruzeiro do Sul, Castro Alves, Floresta Montenegrina, Négo e Rui Barbosa.

${ }^{27}$ Sociedades esportivas e recreativas de Novo Hamburgo que, no passado, foram reconhecidas como importantes espaços de sociabilidade dos descendentes de imigrantes alemães.
} 
que Novo Hamburgo não tem mais dinheiro, mas tem muita gente rica em Novo Hamburgo. O problema são "os barzinhos". Hoje, as pessoas têm festa de segunda a segunda. Segunda eles vão no Alternativo, ${ }^{28}$ tem o Hamburger Bier, ${ }^{29}$ tem não sei o quê, é muita opção. A Sociedades ficam de lado, ficam em segundo plano. O que vai acontecer? Os caras vão dizer: "Ah, exigem um monte de coisas... eu não vou lá”. O Cruzeiro, qual é o problema do Cruzeiro? Apesar de ser uma sociedade negra e pobre, os caras também dizem: "Ah, eu não vou lá no Cruzeiro... porque eu tenho um barzinho lá que eu posso ir”. Tem um monte de outros lugares que eles podem ir. E lá no Cruzeiro não tem um... hoje eu não tenho um teto, uma coisa sólida pra cativar e trazer esse pessoal pra dentro. Então, esse é o grande problema, não é só o negro, já é uma coisa meio geral, pra todo mundo. Aí começaram as reuniões. De dois em dois meses fazemos a reunião em uma das sociedades. Daí ficou assim: a gente faz uma festa no ano, cada sociedade tem uma festa no ano que o coletivo se encontra. Até esse coletivo ficou definido numa reunião no Rui Barbosa, ficou definido que o nome seria Coletivo de Sociedade Negras do Brasil. (...) O Coletivo é mais aqui (no RS). Falando no Cruzeiro, eu optei pelo aniversário do Cruzeiro. Nesse dia, vêm todos os coletivos. (...) Ficou definido assim: cada sociedade fica responsável de levar quinze pessoas. Nem que não vão quinze pessoas tu tens de pagar os quinze cartões que são designados para aquela sociedade. No ano passado todas as festas foram muito boas. Fomos à Venâncio, fomos a Canoas. Inclusive em Venâncio Aires predominam as mulheres na diretoria do Négo. (...)Há muitos anos atrás o Cruzeiro fazia muita reunião. Cachoeira do Sul o Cruzeiro foi, o Cruzeiro é conhecido em todas as regiões de Santa Maria. Inclusive, quando nós fomos a Santa Maria eu perguntei ao pessoal: “Conhece o Cruzeiro?” Quando eu fui em Santa Maria, o pessoal do Chove e não Molha lá de Pelotas, todo mundo conhece o Cruzeiro. Como é uma sociedade antiga, é muito conhecida. Antigamente a integração das sociedades era mais fácil, o pessoal ia de trem, ia de qualquer jeito, mas o pessoal ia, fazia integração. (...) Pelo que as minhas tias falam o Cruzeiro era uma sociedade negra de elite. Eram "os fulanos". E tinham os negros mais pobres. Pelo que me contaram o Marujos foi fundado por essas pessoas, porque foram discriminados na época pelos mais da elite, isso é o que contam. (Ademir da Silva, abr. 2008. Entrevista gravada).

A partir da criação do coletivo estreitaram-se os laços de solidariedade e de ajuda mútua entre as sociedades envolvidas. Em geral, as atividades desenvolvidas por uma ou outra sociedade são divulgadas e inseridas numa espécie de calendário geral do coletivo. Durante o ano, podem-se ver cartazes e folders de divulgação dos eventos das outras sociedades afixados nas paredes da sede da Sociedade Cruzeiro.

Dentre as possibilidades abertas pelas ações afirmativas em Novo Hamburgo está o início de uma discussão sobre o reconhecimento de alguns espaços como patrimônio histórico e cultural afro-brasileiro da cidade e da região. Esse é o caso da Sociedade Cruzeiro do Sul.

Num momento em que diversas cidades do Vale “fabricam” identidades culturais, reforçando pertencimentos étnicos e os transformando em "mercadorias”, as comunidades negras, estimuladas pelo debate das ações afirmativas, lançam mão da distintividade étnico-racial como forma de romper com o discurso da invisibilidade da presença negra na região, como também

\footnotetext{
${ }^{28}$ Danceteria, point da juventude da região, localizada na RS 239, perto do bairro São Jorge.

${ }^{29}$ Cervejaria localizada na RS 239, na Vila Nova, nas proximidades do campus 2 da Feevale.
} 
ampliar o acesso a direitos econômicos, sociais e culturais, bens e serviços, buscando inserir os espaços e expressões da cultura afro-brasileira no mercado de bens culturais e simbólicos da cidade e da região.

Há um esforço da atual diretoria da Sociedade Cruzeiro do Sul para reunir objetos, documentos, fotografias, que possam ajudar a compor a narrativa sobre a história dos negros no Vale do Sinos. A Sociedade acredita que o conjunto desses registros possa auxiliar no reconhecimento da Sociedade como patrimônio cultural afro-brasileiro. Mais do que ajudar a narrar a "história” dos negros no Vale, as fotografias revelam o esforço dessa comunidade para juntar os fragmentos dessa história.

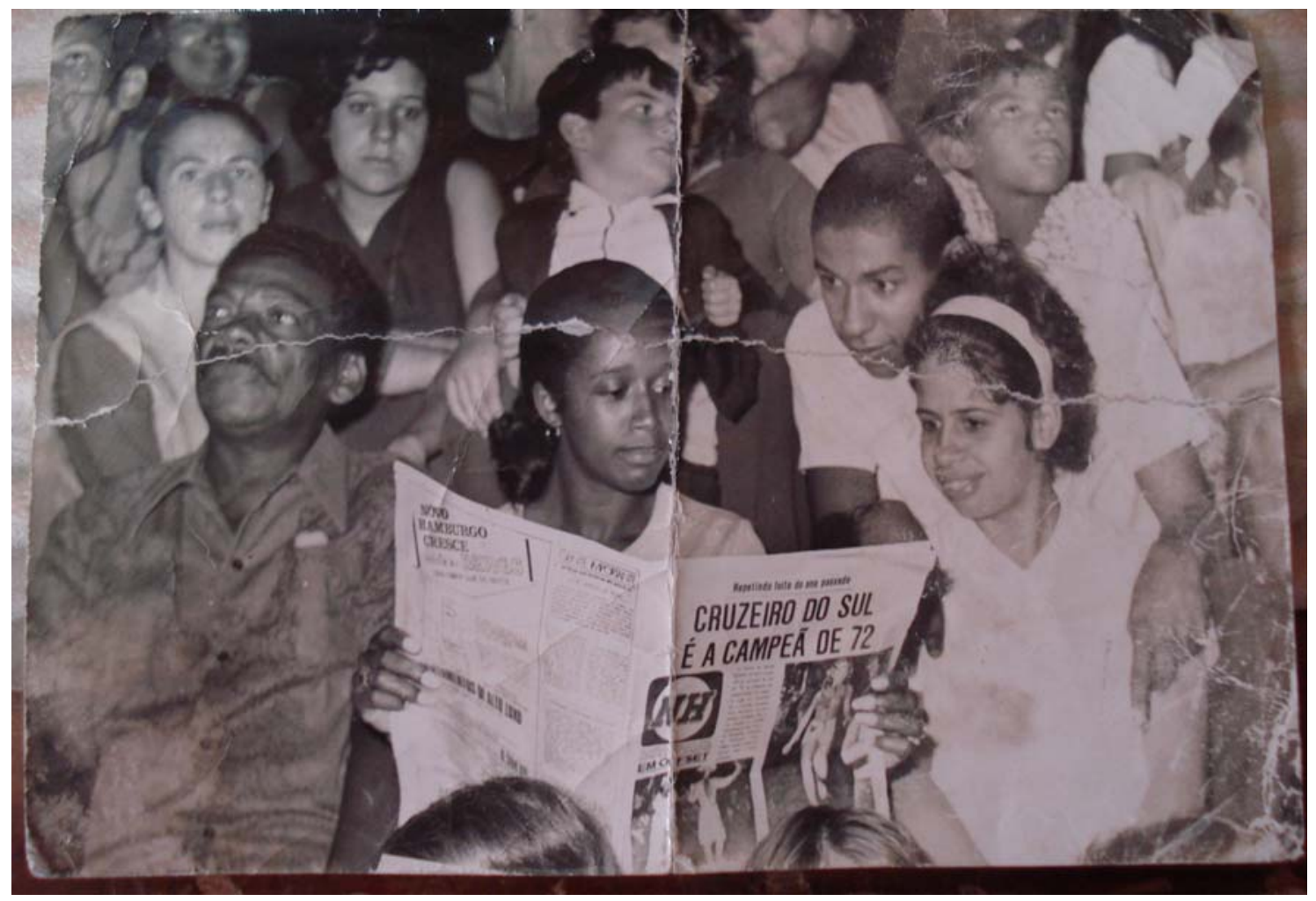

Cruzeiro do Sul, campeã de 72. (Autoria desconhecida).

Fotografia do acervo da Sociedade Cruzeiro do Sul.

Material autorizado para reprodução. Set. 2008.

Reprodução da imagem: Margarete F.Nunes

\section{Considerações finais}

As diferenças étnicas no mundo urbano contemporâneo têm sido transformadas em signos de reconhecimento, passam por um processo de “culturalização”, e o social também se 
transmuta em “objeto cultural”, é repensado, reinterpretado, servindo de encenação às memórias coletivas.

As comunidades negras, devidamente estimuladas pelas políticas de ações afirmativas, também participam, ao lado de outros grupos, do jogo de etnicização das paisagens urbanas, reivindicando o direito de que seus espaços de expressão cultural não sejam apenas aceitos, mas valorizados, reconhecidos e tão dignos quanto outros à “patrimonialização”. Esta “objetalização da cultura” (Jeudy, 1990) faz do étnico, força aglutinadora e mobilizadora da vida urbana contemporânea; as trajetórias dos sujeitos e suas “narrativas étnicas” adquirem um papel fundamental na constituição dos novos patrimônios.

Ao acionarem o recurso da memória, os negros começam a desvendar os mecanismos de dominação que estimularam os “esquecimentos” e "lembranças” da sua "história coletiva”, sejam estes vistos sob a perspectiva nacional, regional ou local. Dessa maneira, abrem brechas para a ampliação do debate sobre a democratização da cidade, o direito e o acesso aos seus bens culturais e simbólicos. À medida que este debate ganha vulto vai-se revelando uma tensão, uma controvérsia entre a memória social e a memória coletiva, pois as narrativas desses sujeitos mostram as diferenças étnico-raciais e suas “distinções simbólicas” (Bourdieu, 1983), isto é, mostram como ocorreu a materialização desses valores por meio da reprodução de formas objetivas de segregação e discriminação raciais ao longo do tempo.

Os negros, vêem-se, então, envolvidos na tarefa de estabelecer uma nova lógica cultural, uma nova produção de sentido que dê conta de problematizar essa assimetria na atribuição de valores aos diferentes grupos étnico-raciais formadores da sociedade brasileira.

Em Novo Hamburgo, ao lado de uma “memória alemã” insinua-se a instauração de uma “memória negra”, legitimada também pelo trabalho de historiadores e antropólogos. Este movimento, apesar de incipiente, pode revelar uma mudança lenta e gradual do processo de invisibilidade social e simbólica do negro no Rio Grande do Sul (Oliven, 1996).

As cidades brasileiras estão sendo pressionadas a instaurar outra dinâmica cultural, que é a de valorização das memórias coletivas dos seus grupos étnicos formadores. Os antropólogos põem-se a serviço dessa dinâmica cultural, por meio da produção de etnografias que auxiliem neste trabalho de “reconstituição da vida social e cultural” dos grupos (Jeudy, 1990). 


\section{Referências}

ALVES, Eliege Moura. Uma presença invisível: escravos em terras alemãs (1850-1870). In: Nunes, Margarete F. Diversidade e Políticas Afirmativas: diálogos e intercursos. Novo Hamburgo: Feevale, 2005.

ANSALDI, Waldo. La Memoria, el olvido y el poder. In: POSSAMAI, Zita; ORTIZ, Vitor (orgs.). Cidade \& Memória na Globalização. Seminário das Mercocidades. Porto Alegre: Secretaria Municipal da Cultura, 2002.

AUGÉ, Marc. Por uma Antropologia dos Mundos Contemporâneos. Rio de Janeiro: Bertrand Brasil, 1997.

BOURDIEU, Pierre. Gostos de Classe e Estilos de Vida. In: ORTIZ, Renato (org.). Pierre Bourdieu. Sociologia. São Paulo: Ática, 1983.

CANEVACCI, Massimo. A Cidade Polifônica. Ensaio sobre a antropologia da comunicação urbana. São Paulo: Studio Nobel, 1997.

CASTRO, Mary Garcia. Transidentidades no local globalizado. Não-identidades, margens e fronteiras: vozes de mulheres latinas nos E.U.A. In: FELDMAN-BIANCO, Bela; CAPINHA, Graça. Identidades: Estudos de Cultura e Poder. São Paulo: Hucitec, 2000.

DURAND, Gilbert. As Estruturas Antropológicas do Imaginário. 3.ed. São Paulo: Martins Fontes, 2002.

ECKERT, Cornelia. Ritmos e ressonâncias da duração de uma comunidade de trabalho: mineiros do carvão (La Grand-Combe, França). In: Cadernos de Antropologia, n. 11. Porto Alegre, PPGAS, 1993, 84 p.

. O que não esquecemos? Tudo aquilo que temos razões para recomeçar. In: POSSAMAI, Zita; ORTIZ, Vitor (orgs.). Cidade \& Memória na Globalização. Seminário das Mercocidades. Porto Alegre: Secretaria Municipal da Cultura, 2002.

ECKERT, Cornelia e ROCHA, Ana Luiza Carvalho da. O Tempo e a Cidade. Porto Alegre: Editora da UFRGS, 2005.

FERNANDES, Florestan. O Negro no Mundo dos Brancos. São Paulo: Global, 2007. GANCHO, Cândida Vilares. Como Analisar Narrativas. 7a ed. São Paulo: Ática, 2000.

HALBWACHS, Maurice. A Memória Coletiva. São Paulo: Centauro, 2006.

JEUDY, Henri-Pierre. Memórias do Social. Rio de Janeiro: Forense Universitária: 1990.

LEITE, Rogério Proença. Contra-Usos da Cidade. Lugares e Espaço Público na Experiência Urbana Contemporânea. Campinas, SP: Editora UNICAMP; Aracaju, SE: Editora UFS, 2004.

MAFFESOLI, Michel. O Tempo das Tribos. O Declínio do Individualismo nas Sociedades de Massa. Rio de Janeiro: Forense-Universitária, 1987.

. A Contemplação do Mundo. Porto Alegre: Artes \& Ofícios, 1995.

. No Fundo das Aparências. Petrópolis, RJ: Vozes, 1999.

MAGALHÃES, Magna L. Negras Memórias: a trajetória da Sociedade Cruzeiro do Sul. In: NUNES, Margarete F. Diversidade e Políticas Afirmativas: diálogos e intercursos. Novo Hamburgo: Feevale, 2005.

MAGNANI, José Guilherme Cantor. Quando o Campo é a Cidade: fazendo antropologia na metrópole. In: Na Metrópole. Textos de Antropologia Urbana. São Paulo: EDUSP, 1996. Disponível em: < www.n-a-u.org/QUANDOOCAMPOCAPI.pdf> Acesso em 24 jan. 2008.

. De Perto e de Dentro: notas para uma etnografia urbana. Revista Brasileira de Ciências

Socias, São Paulo, v.17, n.49, 2002. Disponível em: http://www.n-au.org/DEPERTOEDEDENTRO/html. Acesso em: 24 jan. 2008. 
- A Antropologia Urbana e os Desafios da Metrópole. Tempo Social. Revista de Sociologia da USP, São Paulo, v.15, n.1, 2003. Disponível em:< www.n-au.org/AntropologiaUrbanadesafiosmetropole.html > Acesso em: 24 jan. 2008.

WEIMER, Günter. Construtores Alemães do Rio Grande do Sul (1845-1865). In: MÜLLER, Telmo Lauro (org.) Imigração e Colonização Alemã. Porto Alegre: EST, 1980.

MUNANGA, Kabengele. Uma Abordagem Conceitual das Noções de Raça, Racismo, Identidade e Etnia. Disponível em: <http://www.acaoeducativa.org.br/downloads/09abordagem.pdf > Acesso em: 20 maio 2006.

NUNES, Margarete. Fagundes. "O Negro no Mundo Alemão": cidade, memória e ações afirmativas no tempo da globalização. Florianópolis, UFSC, 2009. Tese (Antropologia Social), Centro de Filosofia e Ciências Humanas, Universidade Federal de Santa Catarina, 2009.

OLIVEN, Ruben. A Invisibilidade Social e Simbólica do Negro no Rio Grande do Sul. In: LEITE, Ilka Boaventura (org.). Negros no Sul do Brasil: Invisibilidade e Territorialidade. Florianópolis: Letras Contemporâneas, 1996.

ORTIZ, Renato. Cultura Brasileira e Identidade Nacional. 5 ed. São Paulo: Brasiliense, 1994.

PARK, Robert Ezra. A Cidade: sugestões para a investigação do comportamento humano no meio urbano. In: VELHO, Otávio Guiherme (org.). O Fenômeno Urbano. Rio de Janeiro: Zahar, 1967.

PETRY, Leopoldo. O município de São Leopoldo. No Anno do I Centenario da Independencia do Brasil. Dados Historicos, Geographicos e Estatisticos Colligidos por Leopoldo Petry. Collector Estadual de Novo Hamburgo. Ex-secretario da Intendencia Municipal de São Leopoldo. 1923.

POUTIGNAT, Philippe; STREIFF-FENART, Jocelyne. Teorias da Etnicidade. Seguido de grupos étnicos e suas fronteiras de Frederick Barth. São Paulo: UNESP, 1998.

RIOS, Roger Raupp. Ações Afirmativas no Direito Constitucional Brasileiro: reflexões a partir de debate constitucional estadunidense. In: SARLET, Ingo W. (org). Jurisdição e Direitos Fundamentais. Anuário 2004/2005 da Escola Superior da Magistratura do Rio Grande do Sul AJURIS. Porto Alegre: Ajuris; Livraria do Advogado, 2006.

ROCHA, Ana Luiza Carvalho da. A Imagem de Si e do Outro, entre a Identidade e a Globalização. Iluminuras - Banco de Imagens e Efeitos Visuais. Porto Alegre, n. 32, 2001. Disponível em: http://www.estacaoportoalegre.ufrgs.br >. Acesso em: 08 jul. 2007.

SAHLINS, Marshall. O "Pessimismo Sentimental” e a Experiência Etnográfica: por que a cultura não é um objeto em via de extinção (parte II). MANA. n.3 (2). p. 103 a 150, 1997.

SASSEN, Saskia. As Cidades na Economia Mundial. São Paulo: Studio Nobel, 1998.

SCHEMES, Claudia et all. Memória do Setor Coureiro-Calçadista: pioneiros e empreendedores do Vale do Rio dos Sinos. Novo Hamburgo: Feevale, 2005.

SHÜTZ, Liene M. Martins. Os Bairros de Novo Hamburgo. Novo Hamburgo: 2001.

SHWARCZ, Lilia Moritz. O Espetáculo das Raças. Cientistas, Instituições e Questão Racial no Brasil. 1870-1930. São Paulo: Companhia das Letras, 1993.

SIMMEL, Georg. A Metrópole e a Vida Mental. In: VELHO, Otávio Guilherme. O Fenômeno Urbano. (org.) Rio de Janeiro, Zahar, 1967.

SODRÉ, Muniz. O Terreiro e a Cidade: a forma social negro-brasileira. Petrópolis: Vozes, 1988.

_. Diversidade e Diferença. Revista Científica de Información y Comunicación, Sevilha,

n.3, $2006 . \quad$ Disponível em:

http://www.institucional.us.es/revistas/revistas/comunicacion/pdf/numero\%203/art1.pdf $>$ Acesso em: 29/07/2008.

VELHO, Gilberto. A Utopia Urbana. 5. ed. Rio de Janeiro, Zahar, 1989. 
. Projeto e Metamorfose: antropologia das sociedades complexas. Rio de Janeiro:Zahar, 1994.

WIRTH, Louis. O Urbanismo como Modo de Vida. In: VELHO, Otávio Guiherme (org.). O Fenômeno Urbano. Rio de Janeiro: Zahar, 1967.

Documentário em DVD

OS CAMINHOS Invisíveis do Negro em Porto Alegre: a tradição do Bará do Mercado. Direção: Ana Luiza Carvalho da Rocha. Produção: Anelise Guterres. Roteiro: Ana Luiza Carvalho da Rocha e Rafael Devos. Programa Petrobrás Cultural. Porto Alegre: OcusPocus Imagens, 2007. 1 doc. (55 min).

Jornais

Semanário 05 de Abril, Novo Hamburgo, ano 1, n.16, 19 ago. 1927. 